\title{
School Culture and Innovation: Does the Post-Pandemic World COVID- 19 Invite to Transition or to Rupture?
}

\author{
Marili Moreira da Silva Vieira \\ Susana Mesquita Barbosa \\ Mackenzie Presbyterian University
}

\begin{abstract}
This article discusses the relations between school culture and the innovation processes necessary for schools, inserted in a complex, globalized, plural and technological society, to continue to meet the needs of their students. It seeks to highlight the educational legacies of the twentieth century (SAVIANI, 2017), the paradigmatic transitions in education (PACHECO, 2019; VALDEMARIN, 2017) and the school rituals that constitute the culture, essential to explain the purposes of the school (not the teaching objectives, but the reason for the existence of the school), and consequently, the definition of the curriculum and the strengthening of teacher's identity (SOUZA, 2017). From the explanation of the school's purpose, we begin to discuss the relationship that it should establish with digital culture and with innovational processes. Crises drive innovation because they create different needs for people (PACHECO, 2019; BENITO, 2017). The moment that is being lived, generating new needs, will drive innovations in educational and schools. It is important to have clarity of the school purpose of education, so that the ruptures and innovations are ethical and might meet the welfare of the students (CORNISH, 2019) and the teachers, as well as the educational needs of an ethical citizen, globally and locally.
\end{abstract}

Keywords: Covid19, School culture, Curriculum, Digital culture, Innovation.

\section{Introduction}

The pandemic experienced in 2020 due to the spread of the COVID-19 Virus provoked serial reactions from different social and economic sectors. The ease of contagion (air routes) and the rapidity of the manifestation and spread of symptoms, caused sovereign states and international communities to decide on collective measures, in some cases, radical measures of isolation and social distancing, aiming to reduce forms of infection and/or slowing their contagion curve.

The pandemic initially hit health care, shed a severe light on the vulnerabilities and challenges facing humanity in respect to all the social rights. Alongside this loss of social rights, we perceived a clear picture of existing inequalities.

Among the measures taken, one that generated the most social and economic impact was undoubtedly the suspension of educational activities around the world with the immediate cancellation of classes and/or educational adaptations, conducting classes using technological 
mediation. More precisely, according to UNESCO data (2020), more than 1.5 billion students had their learning impaired due to the closure of schools.

This situation has raised a series of issues and problems that lead us to reconnect with and rediscover the social role of education; to face and recognize the concrete economic, social and infrastructure inequalities involved in education and, above all, conduct us to reflect upon the very meaning and scope of Education.

In June 2020, UNESCO published a paper intitled "Education in a post-COVID world: Nine ideas for public action" in which it advocates that "We cannot return to the world as it was before" and invites us to think about ways, principles and possibilities to have no educational setback.

Among the guidelines and ideas for post-pandemic education are: 1) The definition of 'right to education ' provided special attention to the issue of connectivity and access to knowledge and to information; 2) Protection of the social spaces provided by schools, considered indispensable, but in which new "school practices' should be observed, preserving the spacetime of collective life; 3) Ensure that scientific literacy within the curriculum, actively placing ourselves against the empire of disinformation (ignorance or fake news) and, 4) Promoting global solidarity to end the current levels of inequality.

We highlight these ideas because, more accurately, they are also part of the discussion that involves School Culture, and impulses us to think on the complexity, inter-relations and continuity of Education, Society and Curriculum. Therefore, to guarantee continuity and to try to understand what this "new normal" will demand of educators, it is essential to acknowledge how school culture and curriculum relate to society. Souza (2017) also points out the same proposal in Sacristán (1998), Forquin (1993):

[...] studies in school culture that can explain the various dimensions of the internal functioning of schools in their relationship with society, particularly the functioning of the curriculum, are indispensable. Raw material of teaching practice and essential reason for the existence of school, as Sacristán states, the concern and focus in curriculum, "the definition of culture and its conditions for development and meaning" in educational institutions, is at the heart of such an undertaking (Sacristán apud FORQUIN, 1993, p. 21).

Hence society is going through a major crisis, educational institutions are also undertaking this crisis and will suffer these effects in its culture and in curriculum. However, will we be able to acknowledge this? In what dimension will school culture and curriculum be affected by this crisis?

Crises drive innovation processes because they create new and different needs for people (Pacheco, 2019; Benito, 2017). The moment that is being lived, generating new needs, is expected to drive innovations in educational and school processes. However, to do so, it is important to have clarity of the purposes of school, of education, so that the ruptures and innovations brought forth can meet the educating needs of an ethical citizen, globally and locally.

What kind of changes and innovations do we desire in schools or in the teaching-learning procedures? Do we want schools for new types of citizens? What exactly do we need to change in schools? Will this be an opportunity to promote changes in our teaching methodologies? Or in curriculum? 
As António Viñao (2007) reminds us, every reform, change, or innovation produces anticipated, or even desired effects. Other times, the changes alter behavior or induce the opposite attitudes or, even antagonistic to what had been originally desired. Therefore, new situations need to be reflected upon, so that we can observe the real changes. There are occasions in that the changes will become authentic educational innovations, in other, curricular ones. However, alternations will only really be considered as part of the new school culture when, on the horizon, we glimpse its consolidation and structure during the process.

Much has been asked about the consequences of the pandemic: we are either facing a rupture, in which we will perceive a paradigmatic revolution in all social areas, including education, or we are observing a moment proper to social evolution, in which we will observe transitions of processes and procedures, but we will keep the model already established.

\section{School Culture and Society}

The political, economic, and pedagogical decisions taken in the context of COVID-19 had their implementation in a short period of time but will have long-term consequences. These decisions will impact the analysis of policymakers, the theoretical elaborations of educators and their respective educational communities - which may become transnational.

Since the 1970s, it has been perceived that when we are faced with situations like this, we are led to realize the impact on School Culture. This concept derives from the conception that both school practices and educational processes are part of broader cultural processes (Gonçalves \& Faria Fo, 2005, p.32) and, therefore, every time we have changes in cultural macrostructures we will observe their reflections in School Culture.

António Viñao (2007), a Spanish philosopher, points out that school institutions and educational systems constantly change and, in this process, will perceive different types of relationships with external aspects and with the internal aspects of the system. Therefore, we need to understand the measure, the aspect and the march for changes, and the different lessons that we can perceive in them, namely:

It is therefore necessary to distinguish at least two types of educational changes: those that are due to long-term socio-educational processes - in which external aspects or conditions play a relevant role - and those others, more limited to school but also lengthened over time, of an organizational-curricular nature. This is not, of course, an absolute division. Both changes interact with each other, however their outcome outlines the relationship between school culture, reforms, and innovations.

The fact that in both cases these are long-term processes - longer, in any case, the former - is not the result of chance or a discursive strategy. The first lesson that offers a historical view of school reforms and changes is the contrast between the latter - which usually take place in a slow and almost imperceptible way - and the impatient and noisy clamor of reformers with their calendars and their persistent and failed pretensions to "reinvent" the school. (António Viñao, 2007, p.5. Authors' own translation)

We understand, then, that such a conception must recognize that school norms and practices should be understood in aspects related not only to the context of their production, but also to their purpose, to their time and context, and, in a special way, their primary intention, enabling answers to religious, socio-political or economic inquiries, as it turns out today, sanitary 
inquiries. Therefore, we are dealing with the identification of different school cultures, in the same space-time (geographically and chronologically considered).

Dialoguing with António Viñao, Dominique Julia (2001), a French historian, develops his thesis to justify the potentialities of understanding the concept from his historiographical perspective. For this, the author defends that the analysis of school culture needs to be done in relation to the set of contemporary cultures. Thus, school culture as "a set of norms that define which knowledge to be taught and the behavior to be inculcated, and a set of practices that allow the transmission of this knowledge and the incorporation of these behaviors" (Julia, 2001, p. 10).

Philippe Perrenoud, a Swiss sociologist, understands that there are situations in which school culture can also be analyzed from the perspective of the construction of teachers' savoir-faire, taking into account the possibility that this analysis occurs at times when the "school submits this knowledge, and in a global way, the practices and cultures, to a set of transformations that make it teachable", in a movement ranging from the selection of knowledge, through their didacticization, that is, making it teachable, to the "effective learning of students" (Perrenoud, 1993, p. 25, cited by Gonçalves \& Faria Fo, 2005, p.32).

These great conceptions make us realize that school culture is structurally and systematically linked to great social transformations, dialoguing especially with History, Sociology and Anthropology. This complexity allows us to move on a reflection that can be both comprehensive of the great processes of interlocution, and responsive to the most particular aspects of the school routine.

For this reason, Viñao (2007) went ahead in his thesis by warning us that also the educational systems, the teaching institutions experience in addition to external changes, numerous internal changes, especially circumscribed to the curricular organizational scope. These are changes that can be observed with a 'microscope' and readily identified because they objectively alter the school routine, the 'school doing', such as the insertion of a new discipline, the institution of a new working method or a new technological resource. Changes that, because they are surgical, have a profound and immediate impact on all educational processes and school life.

Reflecting on pedagogical and educational changes, considering the category of School Culture, allows us, therefore, to investigate, guiding a proposal of theoretical and methodological renewal of epistemological contexts, organizational contexts, and disciplinary contexts. This perspective allows schools to appropriate themselves of the meaning their practices convey.

Such concern appears in Michel Young (2007), an English educator, who throws the fundamental and always current question of "What is school for?" In addition to being inserted in the discussion of School Culture, this question should be asked repeatedly by the entire academic community and by society in general, permanently, that is, as an agenda. From the perspective of such an agenda, parents, adults responsible for minors, schools, teachers, and politicians become active participants in the powerful construction of knowledge.

More than raising the question, the author reminds us that such an analysis is vital for the Sociology of Education, because the question of the awareness of intentionality (What is it for? ) is what guarantees autonomy, authority and, above all, the trust that schools have for and with society. (Young, 2007) 
The complex literature on School Culture reveals "pandora's box of school education", as Julia (2001) would define. Benito (2017), for this reason, reminds us that school culture is a legitimate pedagogical heritage - material and immaterial. The historiography of school culture allows us to reach its biographical and social memory, opening the possibility of processing it as a

Patrimonial education focused on the identity of the narrative of the subjects and the formation of a new citizenship. The investigation of the history and culture of the school, from an archaeological perspective, supported by the study of materiality's, their institutional uses, and the narrative value that the actors attribute to it, suggests the construction of a new subjectivity. (Benito, 2017, p. 25)

In an effort, therefore, to understand the locus of contemporary problems and understanding that school culture dialogues with the great social changes (macro) and internalizes them with changes in pedagogical practices and processes, we will dedicate ourselves to establishing parameters and guidelines to understand the changes caused in school culture due to the COVID-19 pandemic.

\section{The unveiling of the world's sensitivity: reflections on the Pandemic}

We try to surround ourselves with the utmost certainty, but to live is to sail in a sea of uncertainty, through islands and archipelagos of certainties in which we refuel. (Edgard Morin. Certainties are an illusion. 2020)

As stated, the Covid-19 pandemic has generated numerous impacts on global society. UNESCO data inform us that the mere suspension of school activities and processes has directly impacted the lives of more than 1 billion inhabitants of the planet, and alone demonstrates the strength of social change. Economic, political, and pedagogical decisions have been made and will impact, for many years, the entire school culture.

The fact is that the COVID-19 pandemic revealed social and economic vulnerabilities including technological infrastructure - in a global way. But, also, it has emerged the extraordinary human resources and potential, capable of giving immediate answers and revealing that pragmatism and rapid actions when based on great principles and under the best purposes.

The statement UNESCO and many world theorists have made is that we cannot return to the world in the same way as it was before. We cannot therefore have institutional arrangements at the international and national level restructured in a way that doesn't dialogue with the principal school actors. As it has not been seen for a long time, for example, decisions regarding the performance of school activities were taken by health authorities, not pedagogical. We became aware of our vulnerable health and of how states and politicians prioritize their actions, especially regarding the construction of public health care systems.

If school culture is impacted by society and vice-versa, shouldn't teachers be heard about how to proceed upon this emergency? Our politicians demonstrated their worries in respect to our fragile health during this pandemic but, little was heard about how to go about the fact that students were without formal education.

Teachers, in many countries, took it into their hands to guarantee a minimum of continuity of education during this period. In doing so, they came in touch and researched new forms of 
teaching and the possibilities of teaching with technology. How will these teachers come back? How will this experience impact school culture?

Philosophers, pedagogues, sociologists, and economists have dedicated themselves to understanding and leading us to reflect upon what we are experiencing. What has been revealed to us? What was unveiled to us? What will be delegated to us?

The Portuguese philosopher Boaventura Santos (2020) wrote a text early in the Pandemic, entitled "The Cruel Pedagogy of the Virus. " " In this paper, he states that it is possible to learn from the "Virus", but this will only happen in fact if we are ready to abandon the world as we knew it before and abandon our desire to return to "normal".

He understands that the virus has revealed the consequences of our options. In the last 40 (forty) years we have not paid attention to the seriousness of ecological issues and to issues related to social and economic inequalities. Therefore, it is not enough for us to have passive attitude of acceptance that we will no longer have the same world.

We need a different attitude, one of promotion of concrete and effective change. Not only to abandon our way of life before the pandemic, but also to position ourselves energetically willing to create a new life, with a new pattern of consumption of nature and, above all, with new ways of participation and political insertion in our communities, among these insertions, direct involvement in the construction of school identity.

The Brazilian indigenist philosopher Ailton Krenak wrote a strong manifesto entitled "Tomorrow is not for sale. "(2020). In it, the indigenist agrees with Boaventura in saying that the pandemic is not a surprise, but rather the consequence of a process of non-legitimation of the knowledge of ancestral cultures, especially those in respect to nature.

He argues that humanity needs to emerge differently from this pandemic and understand that it is not an accident but an incident in the trajectory of the economic and social choices that we take on a daily basis in all our actions. The way out is to re-humanize ourselves; that is, to place man, his dignity, and his preservation as an essential recipient of our actions. What is at stake, therefore, is not only the change of the way of life, but the confirmation or not of our human character:

Let us hope we do not get back to normal, because if we go back, it is because it was not worth the death of thousands of people all over the world. After all that, people will not want to wrangle their oxygen again with dozens of colleagues in a small workspace. [...] We cannot go back to that rhythm[...].

It would be like converting to denialism, accepting that the Earth is flat and that we should keep devouring ourselves. Then, yes, we will have proved that humanity is a lie. (Krenak, 2020, p.14)

Yuval Harari, Israeli historian, is emphatic in stating in an interview that "We will go on living, but we will inhabit a new world"(Harari, 2020). For him, who has dedicated himself to understanding how man dialogues with his historicity, what awaits us is a very rich period, in which we have to discuss essential topics such as privacy, the role of the State, solidarity between nations. However, he, warns that the "[...] the storm will pass. But the decisions we make today will change our lives in the years to come." 
For Harari, the Pandemic delegates responsibility for a new global pact, with the establishment of a new citizenship and a new parameter of humanity. In a unique way and never even imagined by researchers, the pandemic made us live and participate in a 'large-scale social experiment that would never have been approved". At the same time, from the West to the East, in the northern and southern hemispheres, entire societies have altered their daily lives, their eating and hygiene habits, their policies and judicial decisions, and their pedagogical processes.

Thus, if we do not commit ourselves to a new "tomorrow" we run the risk of repeating the dynamics of the twentieth centuries that witnessed numerous emergency situations, in which temporal measures were taken that had the "ugly habit of [not] surviving the emergencies".

The coronavirus epidemic is therefore a great proof of citizenship. In the coming days, each of us will have to choose between relying on scientific data and medical care experts, or unfounded conspiracy theories and political interest. If we do not make the right decision, we could be renouncing our most cherished freedoms, thinking that this is the only way to safeguard our health. (Harari, 2020).

One of the consequences of the pandemic for the author is the empowerment of the new citizen. Among the main changes, he points out that science, education and technology can recover spaces of trust in society - lost especially in recent years -, contribute to the socialization and identification of healthy habits and reduction of health hazards, as well as insert us into participatory democratic processes, since it forced us to follow government decisions and taught us to dimension the risks inherent to them.

The French educator, Edgard Morin, is also a supporter of the idea that we should expect changes. Such changes will focus on the economic, political and, above all, human spheres. In economic changes we will experience a time with new forms of work, differentiated concern with the health and qualification of workers, decision-making processes with less hierarchy. In political changes we will have a resizing of the collective value of solidarity and the culture of consumption. And in human change, we will have to strengthen our humanism, re-establish the criteria for our sense of equality.

The pandemic comes to make us recognize that we are "adrift" of the world. That we very quickly assume the habit of seeing any and all knowledge as dogmas, absolute certainties, however, "Certainties are an illusion".

Science is a human reality that, like democracy, is based on the debates of ideas, although its methods of verification are more rigorous. Despite this, the main accepted theories tend to become dogmatized, and the great innovators have always fought for their findings to be recognized.

The episode we are going through today may therefore be arousing the right time to make citizens and researchers aware of the need to understand that scientific theories are not absolute, like the dogmas of religions, but biodegradable. (Morin, 2020)

In this biodegradable world, the pandemic presents itself as an opportunity to become permanently aware of these human truths that we all know, but which are repressed in our subconscious: that love, friendship, communion, solidarity are what make the quality of life.

In the same perspective, the Spanish educator and sociologist Manuel Castells, sentences: The world has already changed; never more will it be as we know it! This unveiling, as if in a hurry 
to pluck the band-aid from the skin, is what should guide us. Castells points out that our task now is to ask, "how the world has changed?" and no longer "will it change?".

Among the many modifications, the philosopher bets that Education has been hit the fastest. For him, online education will gain more and more space and more quality, especially breaking prejudiced barriers that have been sustaining themselves in recent decades. However, this will not be possible if there is no change of political orientation. If there was one thing that the pandemic revealed to us is that we are inserted in a global society in which there is a deep technological inequality, as well as social inequality and it reveals itself in all areas.

What is most interesting, and with which we utterly agree, for him, face-to-face teaching will never disappear, because his "band width is much higher than that of the fiberoptic network. " (Castells, 2020a). In this way, we can expect as a consequence "A great frontier of pedagogical innovation and investment in teaching," faced with the perception that Education is a fundamental part of the social fabric and, above all, of the civilizing process. The educator says that now is the time for humanity to make a 'great reset'.

However, the biggest reset, is the one that is happening in our heads and lives. It is that we have realized the fragility of everything we believed guaranteed, of the importance of affections, of the resource of solidarity, of the importance of an embrace - and that no one will take us away, because it is better to die embraced than to live in fear.

It is to feel that the consumer waste in which we mistakenly spend our resources is not necessary, because we need no more than a few eats and drinks with friends on the balcony. [...]

The necessary reset is a portal to a new way of life, another culture, another economy. It is good that we value it, because the alternative to it is the masochistic nostalgia of a world that is gone not to return.

Life goes on, but another life. It's up to us to make it wonderful." (Castells, 2020b)

There is no denying the impact of the Pandemic on the world. Not only for their expressive numbers, but above all for the depth of dialogue and reflections on the cultural changes that we are facing and that we will face.

The pandemic has revealed to us, more as confirmation than innovative postulation, that such changes are directly proportional to our choices, including those related to nature. It revealed to us the possibility of a new humanitarian pact, sensitive to the world, to citizenship, attentive to the desires of men and women. And it delegated to us the responsibility to promote reflection upon, and change about the world in which we live, our options and our forms of cultural appropriation.

As we can all verify, the pandemic reaffirmed that one of the most sensitive and powerful aspects in our society is education and, its basic social institution, the School. The School was one of the institutions that most quickly responded to new needs, as it was already rehearsing an insertion of innovative and digital culture. And it did so without losing sight of, rather reinforcing, its social and political dimension.

Jane Soares de Almeida says that this is the belief of all those who are dedicated to the understanding of Education: 
Even recognizing [...] difficulties in the immanent educational field [...] they share the belief in a school that, in the labyrinthine universal entropy, characteristic of present times, still becomes one of the last bulwarks of peoples' hope, whether belonging to this or to that nation, as part of a globalized world that has never shown so many human similarities before the useless social abysses. (Saviani, Almeida, Souza \& Valdemarin, 2014, p.3)

\section{School Culture and Digital Culture in the Pandemic: changes or ruptures}

As we have seen, social conditions change. Naturally, due to their expected and desired processes of transformation, or abruptly, in the face of a need that is imposed.

If cultures change, so do institutions. Thus, as António Viñao (2007) states, educational institutions change. The educator tells us that such changes are fruit of a combination, among many other possibilities and imaginations, of the constant tension between tradition and innovation, notably as a consequence of decisions limited sometimes by external factors, sometimes by technological constraints, sometimes by alteration of practices and processes. All these elements can be grouped into the concept of School Culture.

"[...]This term, of ambiguous and polysemic significance, comprises, in its historical perspective, as stated, a set of ways of doing and thinking, of beliefs and practices, of shared mentalities and behaviors within educational institutions, which are passed on to new members of the school community, especially teachers and students, and that provide strategies to integrate, interact and carry out, especially in the classroom, the tasks that are expected of each one, as well as, at the same time, to meet the demands and limitations they involve or transport. " (Viñao, 2007, p.09)

In effect, we have experienced, as teachers, two different kinds of stimulus for change in our daily practices that might possibly influence our School Culture. On one hand, as already pointed out, the inequality due to the low technological access students have for their learning experiences and for accessing information is an aspect that governments and school administrators will need to face. This unveiling, if ignored, will reveal unethical intentions. It is something that necessarily needs to be faced.

On the other hand, many teachers were faced with the possibility of altering their methods of teaching using the social network students are habituated to use; using different types of APPs and platforms created for sharing and collaborating on line, that necessarily existed, but did not enter into our daily lesson plans. The challenge we now face, when we return to our physical classrooms is to blend our meetings with activities that implicate the students in creating and interacting with each other on-line, using these app. We are challenged to comprehend that technology will not substitute teachers but will enhance their capability of provoking learning and communication with students in a more constant manner, as these technologies for communication permit.

Akash Singhal, a CEO in India, states that:

By the time this pandemic will be defeated, we also have a chance of overcoming all the problems and cons related to the traditional and unorganized form of schooling.

E-learning services, coupled with Collaborative LMS offering such as - Auto-Quiz creation, teachers performance reviews, expertly curated content library, one tap-assignments, Instant messaging, and doubt clearing sessions, etc. will become the best friends of the whole education fraternity. (Singhal, 2020) 
However, as pointed out earlier, these experiments, if not accurately reflected and thought about, will dissipate when we return. We will not survive the crises if we do not think about it seriously. As pointed out by Castells, face-to-face teaching will never go away, but it will gain new force, new energy. Nevertheless, only if closely thought about and seriously related to prior experiences and prior knowledge of what it means to teach, to learn, to be in school.

In an interview given to The Harvard Gazette, former secretary of Education for Massachusetts, Paul Reville, stated:

In politics we say, "Never lose the opportunity of a crisis." And in this situation, we do not simply want to frantically struggle to restore the status quo because the status quo was not operating at an effective level and certainly was not serving all of our children fairly. There are things we can learn in the messiness of adapting through this crisis, which has revealed profound disparities in children's access to support and opportunities. We should be asking: How do we make our school, education, and child-development systems more individually responsive to the needs of our students? Why not construct a system that meets children where they are and gives them what they need inside and outside of school to be successful? Let us take this opportunity to end the "one size fits all" factory model of education. (Reville, 2020)

School culture was already being put in "check" before the pandemic because we weren't communicating with this generation of students of the XXI century, we weren't meeting their needs. Ate the same time, we observe that when challenged to learn using technology and apps, this generation has much difficulty, because, they know how to use it for leisure, for social communication, but not for studying, not for systematization of knowledge. For that, they need the teacher's mediation.

Now, we are at a turning point. We need to be conscious of this; we need to seek more training and more abilities to insert these resources in our pedagogy. But we can't turn back. It is important to reevaluate School Culture and to understand how it will be impacted from this experience. It is our, the teachers', the responsibility to do so and to bring forth this discussion in society. Will we make small changes, adaptations, that in the first opportunity will fall back into old habits? Or will we rupture with old paradigms?

\section{Conclusion}

This paper started out problematizing how the COVID 19 virus and the closing is affecting the role of education and its political, economic, social, and infrastructural impact on society and from society.

The challenge made in June 2020, by UNESCO, and made opportune by ICSS, to write in defense of the idea that "We cannot return to the world as it was before" was faced by the discussion we proposed, so that some principles were raised.

Among the many guidelines already pointed out, this paper aimed to consider two important aspects that involve the "right to education" and interact with the concept of School Culture.

First, a structural change: the confrontation of the necessity to extend access to information to all types of students and populations, expanding connectivity as one of the demands for education. 
In second place, the need for all educators to recall on the significance and the aspects that contribute and constitute what is called School Culture and the effects of forced on-line teaching on this culture, in order to guarantee adequate interaction amidst Society, Education and Curriculum.

We discussed how curriculum relates with valued knowledge in society and how the movements and events lived socially influence education, because they create new needs, new behavior, new forms of interaction. And in school, all these aspects come together composing school culture.

Another concept discussed in this paper relates to how COVID19 unveiled our social weaknesses, our contradictions, our prejudice, the inequality, our fragile health systems. However, it also unveiled our characters, for good, for solidarity, for courage. It revealed how teachers, even if with small conditions deficient abilities involving technology, are committed with their students, with their professions.

We affirmed that this crisis being experienced might generate innovation, but to do so, will necessarily demand clarity about the purpose of schools in society, and teachers and educators, as a whole, will have to reflect upon the experience and the new possibilities that it brought to teaching and to student's development. This commixture of elements historically composing our ideas of schools, teachers and of students, along with the on-line teaching and on-line learning experienced, the technology, the learning platforms and the use of social networks all compose a possible new school culture.

Each community, each school district, each school will need to "look in the mirror" and examine the needs of its own students, the conditions that need confronting and change. This is the opportunity to do so.

Altogether, school culture dialogues with the great social changes (macro) and internalizes them with changes in pedagogical practices and processes. Nonetheless, teachers will need to navigate in uncertain oceans, find new islands to rest and reflect, but the rupture will happen when we all, as teachers, realize that the new culture implies a restlessness that resists the establishment of new dogmas, and promotes continuous pursuit for satisfying new needs and demands of new generations and of society.

\section{References}

[1] BANNELL, R.; DUARTE, R.; CARVALO, C.; PSCHETOLA, M.; MARAFON, G.; CAMPOS, G. (2017) Educação no século XXI. Campinas: Vozes.

[2] BENITO, A.E. (2017) A escola como cultura: experiência, memória e arqueologia. (H.H.P Rocha \& V.L. G. Silva, Trad) - Campinas, SP, Editora Alínea

[3] CASTELLS, M. (2020, April 14 ) Castells debate pandemia, Público e Educação .Outras Palavras. . Retrieved from: <http:// https://outraspalavras.net/pos-capitalismo/castells-debate-apandemia-o-publico-e-a-educacao/>

[4] CASTELLS. M. (2020, April 27) The time of big Reset. Outras Palavras, 27-04-2020. A (S. Paz, trad). Retrieved from: http://www.ihu.unisinos.br/78-noticias/598423-castells-a-hora-dogrande-reset

[5] CORNISH, C. (2019) Student welfare: complexity, dilemmas and contradictions. Research. In: Post-Compulsory Education, 24:2-3, 173-184,

[6] GONÇALVES, A \& FARIA FO, L. (2005). História das Culturas e das Práticas Escolares perspectivas e desafios teórico-metodológicos. In A cultura escolar em debate: questões 
conceituais, metodológicas e desafios para a pesquisa. Souza \& Valdemarin (orgs.). Campinas, SP: Autores Associados.

[7] HARARI, Y. N. (2020, March 24). Yuval Noah Harari: the world after coronavirus. The Financial Times. Retrieved from< http: https://www.ft.com/content/19d90308-6858-11ea-a3c91 fe6fedcca75>.

[8] JULIA, D. (2001). A cultura escolar como objeto historiográfico. (Gizele de Souza, Trad). Revista Brasileira de História da Educação, São Paulo, n. 1, 2001, p. 9-44.

[9] KRENAK, A. (2020). O amanhã não está à venda. São Paulo/Brasil: Companhia das Letras.

[10] MORIN, E. (2020, April 09). As certezas são uma ilusão. Le Journal, CNRS-Retrieved from < https://www.fronteiras.com/entrevistas/edgar-morin-as-certezas-sao-uma-ilusao>.

[11] PACHECO, J. (2019) Inovar é assumir um compromisso ético com a educação. Campinas: Editora Vozes.

[12] REVILLE, P. (2020). Time to fix American education with race-for-space resolve. Retrieved from: <https://news.harvard.edu/gazette/story/2020/04/the-pandemics-impact-on-education/.>

[13] SANTOS, B. S (2020). A cruel pedagogia do vírus. Lisboa: Almedina.

[14] SAVIANI, D. (2017). O legado educacional do Século XX no Brasil. Autores Associados. Edição do Kindle.

[15] SAVIANI, D., ALMEIDA, J.S., SOUZA, R.F, VALDEMARIN, V.T (2014). O legado educacional do século XX no Brasil. (3. Ed). - Campinas, SP.' Autores Associados, 2014.

[16] SILVA, F.C.T. (2006) School Culture: conceptual framework and research possibilities. Educar. Curitiba, Editora UFPR, n. 28, p. 201-216.

[17] SINGHAL, Akash. (2020, July 05) How shift to e-learning during Covid-19 lockdown will lead to paradigm shift in education. India Today. Retrieved from: https://www.indiatoday.in/education-today/featurephilia/story/how-shift-to-e-learningduring-covid-19-lockdown-will-lead-to-paradigm-shift-in-education-1675338-2020-05-07.

[18] UNESCO. (2020). International Commission on the Futures of Education. Education in a postCOVID world: Nine ideas for public action. Paris, UNESCO. Retrieved from https://unesdoc.unesco.org/ark:/48223/pf0000373717/PDF/373717eng.pdf.multi

[19] VIÑAO, A. (2007). Culturas Escolares Y Reformas (Sobre La Naturaleza Histórica De Los Sistemas E Instituciones Educativas). Revista Teias, 1(2), 25 p.. Retrieved from https://www.epublicacoes.uerj.br/index.php/revistateias/article/view/23855

[20] YOUNG, M..(2007). Para Que Servem As Escolas? Educação e Sociedade. Campinas, vol. 28, n. 101, p. 1287-1302, set./dez. Retrieved from: http://www.cedes.unicamp.br. 